\title{
APLIKASI MONITORING PENGADUAN DAN KELUHAN PELANGGAN PADA PT. PLN (Persero) AREA BANJARMASIN BERBASIS WEB
}

\author{
Budi Setiadi ${ }^{1}$, Johan Wahyudi ${ }^{2}$ \\ 1 Fakultas Teknologi Informasi, Universitas Islam Kalimantan Muhammad Arsyad Albanjari Banjarmasin \\ Email : budibtc75@yahoo.com \\ 2 Prodi Teknik Informatika, Sekolah Tinggi Manajemen Informatika Komputer (STMIK) Indonesia Banjarmasin \\ Email : johan77@stmik.id
}

\begin{abstract}
ABSTRAK
PT. PLN (Persero) adalah sebuah perusahaan BUMN milik pemerintah yang memiliki fungsi sebagai penyedia sistem ketenagalistrikan nasional yang disalurkan ke seluruh Indonesia. PT. PLN (Persero) merupakan perusahaan publik yang bergerak dibidang jasa sehingga memiliki tanggung jawab besar untuk mampu memberikan pelayanan yang terbaik kepada masyarakat. Pada PT. PLN (Persero) Area Banjarmasin proses monitoring pengaduan dan keluhan pelanggan selama ini masih dilakukan secara manual yaitu datang langsung ke kantor PLN atau menggunakan Telpon 123 yang sering tidak tersampaikan dengan baik bahkan telepon tidak di jawab. Dimana hal tersebut menyebabkan waktu penanganan pengaduan dan keluhan pelanggan menjadi lebih lambat. Hal lainnya yang dapat terjadi dengan pencatatan manual ialah respon balik terhadap suatu pengaduan atau keluhan dari para pelanggan yang cenderung lambat dikarenakan tidak adanya data yeng terperinci serta terintegrasi dengan komputer yang mengakibatkan sulitnya pencarian data, pengolahan data, serta pelaporan atas keluhan dan pengaduan pelanggan yang lambat karena dipengaruhi oleh banyaknya keluhan terhadap layanan. Oleh karena itu di butuhkan aplikasi yang dapat menangani semua permasalahan yang ada saat ini, yaitu dengan adanya Aplikasi monitoring pelayanan pengaduan dan keluhan pelanggan ini dapat membantu proses keluhan para pelanggan serta mempermudah dalam menangani pengaduan yang di perlukan.

Dalam penelitian ini memberikan pandangan tentang keakuratan di dalam proses penyampaian pengaduan dan keluhan pelanggan dengan mempergunakan suatu sistem yang telah berbasis database. Dengan adanya sistem yang berbasis database ini, maka akan mempermudah proses pancarian dan mengupdate suatu data untuk sebuah informasi yang lebih akurat dan lebih tepat waktu sesuai dengan yang diharapkan dan diiginkan oleh pemakai atau user.
\end{abstract}

\section{Kata Kunci : PT. PLN (Persero), Monitoring, Pengaduan dan Keluhan}

\section{PENDAHULUAN}

PT. PLN (Persero) adalah sebuah perusahaan BUMN milik pemerintah yang memiliki fungsi sebagai penyedia sistem ketenagalistrikan nasional yang disalurkan ke seluruh Indonesia. PT. PLN (Persero) merupakan perusahaan publik yang bergerak dibidang jasa sehingga memiliki tanggung jawab besar untuk mampu memberikan pelayanan yang terbaik kepada masyarakat. Pada PT. PLN (Persero) Area Banjarmasin proses pananganan pengaduan dan keluhan pelanggan selama ini masih dilakukan secara manual yaitu datang langsung kekantor PLN atau menggunakan Telpon 123 yang sering tidak tersampaikan dengan baik bahkan telepon tidak di jawab. Dimana hal tersebut menyebabkan waktu penanganan pengaduan dan keluhan pelanggan menjadi lebih lambat.

Hal lainnya yang dapat terjadi dengan pencatatan manual ialah respon balik terhadap suatu pengaduan atau keluhan dari para pelanggan yang cenderung lambat dikarenakan tidak adanya data yeng terperinci serta terintegrasi dengan komputer yang mengakibatkan sulitnya pencarian data, pengolahan data, serta pelaporan atas keluhan dan pengaduan pelanggan yang lambat karena dipengaruhi oleh banyaknya keluhan terhadap layanan. Oleh karena itu di butuhkan aplikasi yang dapat menangani semua permasalahan yang ada saat ini, yaitu dengan adanya Aplikasi monitoring pelayanan pengaduan dan keluhan pelanggan ini dapat membantu proses keluhan para pelanggan serta mempermudah dalam menangani pengaduan yang di perlukan. 
Dalam penelitian ini memberikan pandangan tentang keakuratan di dalam proses penyampaian pengaduan dan keluhan pelanggan dengan mempergunakan suatu sistem yang telah berbasis database. Dengan adanya sistem yang berbasis database ini, maka akan mempermudah proses pancarian dan mengupdate suatu data untuk sebuah informasi yang lebih akurat dan lebih tepat waktu sesuai dengan yang diharapkan dan diiginkan oleh pemakai atau user.

\section{METODE PENELITIAN}

Metode penelitian yang digunakan dalam pembuatan program ini terdiri dari beberapa langkah yaitu :

1. Metode Pengumpulan Data

Penelitian ini menggunakan beberapa metode pengumpulan data.
a. Studi Kepustakaan
b. Observasi
c. Wawancara

2. Metode Pembangun Perangkat Lunak

Dalam metode ini dilakukan beberapa tahapan sebagai berikut :
a. Analisis
b. Perancangan
c. Implementasi
d. Pengujian
e. Pemeliharaan

\section{HASIL DAN PEMBAHASAN}

Setelah sistem dianalisis dan didesain maka akan menuju tahap implementasi. Implementasi merupakan tahap meletakan sistem sehingga siap diproses dan memiliki tujuan untuk mengkonfirmasi pada modul-modul perancangan, sehingga pengguna dapat memberi masukan kepada pengembangan sistem.

Dalam mendesain sebuah sistem Database diperlukan beberapa kompunen antara lain :

\section{Sistem Konteks Diagram}

Diagram konteks merupakan suatu diagram alir yang menggambarkan arus pengolahan data secara garis besar atau keseluruhan. Diagram konteks ini dirancang untuk mengetahui masukan dan keluaran yang dibutuhkan oleh sistem, serta menggambarkan hubungan antara sistem dan entitas yang terlibat. Untuk lebih jelasnya diagram konteks untuk sistem monitoring pengaduan dan keluhan pelanggan pada PT.PLN Area Banjarmasin bisa diliat diagram konteks dibawah ini.

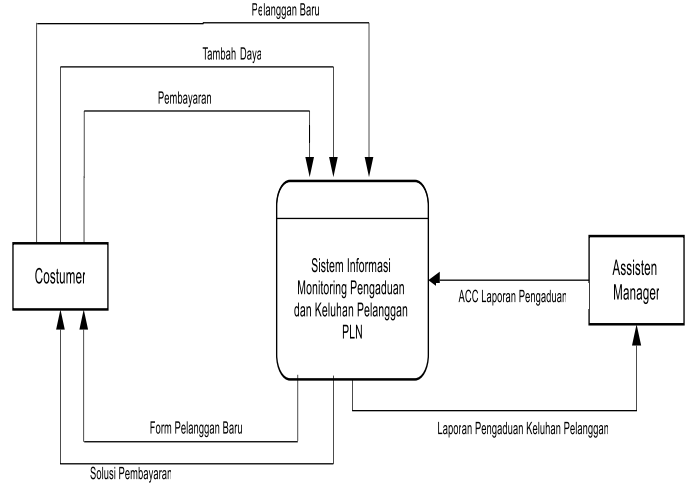

Gambar 1. Diagram Konteks

\section{HIPO}

Berikut ini adalah struktur HIPO dari sistem aplikasi monitoring pengaduan dan keluhan pelanggan. Dalam HIPO ini digambarkan secara global proses-proses yang ada di dalam sistem yanf dibuat.

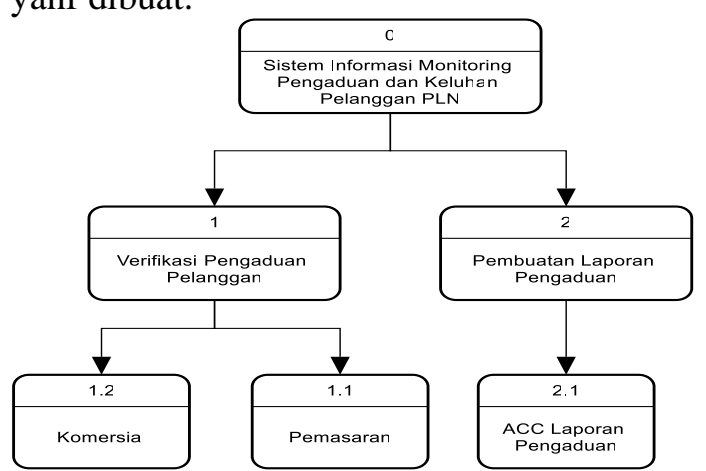

Gambar 2. HIPO Sistem Monitoring Pengaduan dan Keluahan Pelanggan

\section{Data Flow Diagram}

Data Flow Diagram pada sistem monitoring pengaduan dan keluhan pelanggan pada PT. PLN(Persero) Area Banjarmasin, dalam DFD level 0 digambarkan secara global proses-proses apa saja yang ada dalam sistem monitoring ini. Adapun beberapa data yang digunakan antara lain pengaduan tambah daya, pencatatan angka meter, pembayaran, rekap laporan pengaduan, yang dalam prosesnya membutuhkan dan menghasilkan informasi dari dua eksternal entity yaitu pelanggan dan asistem manager. 


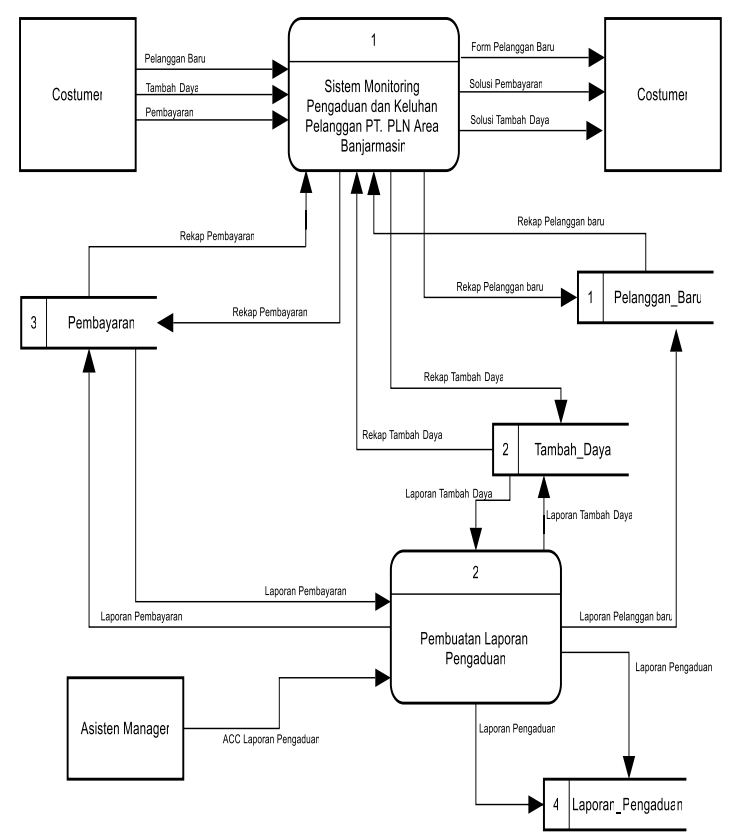

Gambar 3. DFD Sistem Monitoring Pengaduan dan Keluhan Pelanggan

\section{Relasi Antar Tabel}

Adapun relasi antar tabel dalam sistem monitoring pengaduan dan keluahan pelanggan ini dapat di gambarkan sebagai berikut :

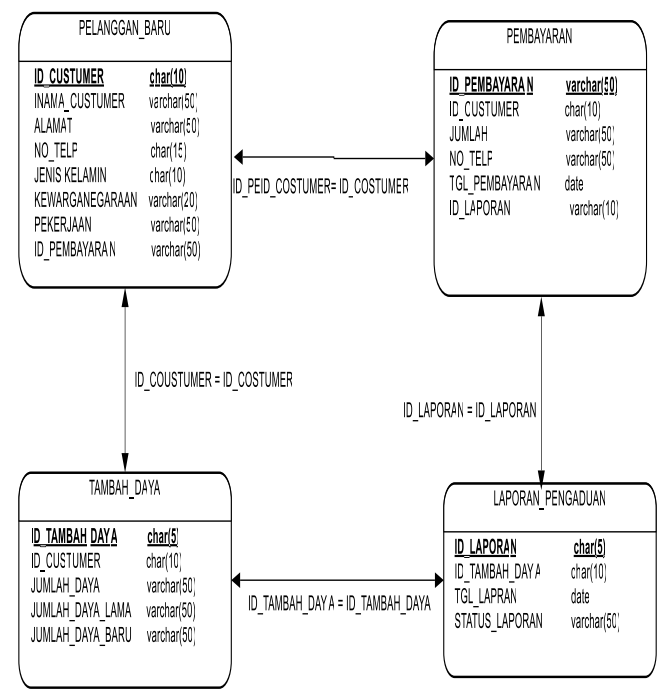

Gambar 4. Relas Antar Tabel

\section{Antarmuka Sistem}

Tampilan awal dari sistem informasi ini masih dibuat secara sederhana, penulis berusaha untuk merancang tampilan dengan sebaik mungkin sehingga dapat mewakili seluruh aspek aspirasi penulis, adapun rancangan tampilan awalnya adalah sebagai berikut:

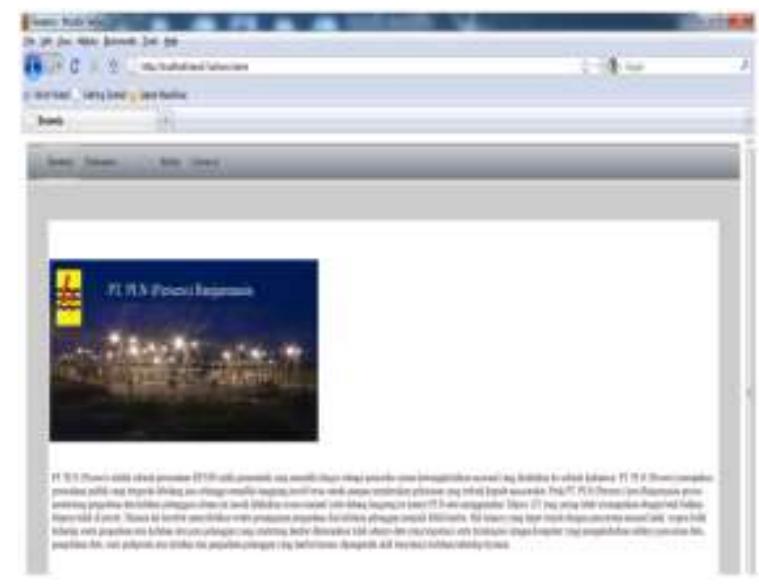

\section{Gambar 5. Menu Utama Sistem Monitoring}

Keterangan :

Pada saat aplikasi dijalankan, maka akan tampil form menu awal yang akan meminta pengguna untuk login sesuai dengan user yang telah diberikan. Form Tampilan Utama merupakan form ketika admin berhasil melakukan login dengan menggunakan username dan password sesuai data dalam database. Berikut adalah gambar form Tampilan Utama Aplikasi Monitoring Pengaduan dan Keluhan Pelanggan

\section{Form Menu Keluhan}

Form menu keluhan pelanggan merupakan form yang akan di isi oleh pelanggan tentang identitas pelanggan dan jenis keluhan. Berikut adalah gambar form tampilan keluhan Aplikasi Monitoring Pengaduan dan Keluhan Pelanggan adalah sebagai berikut:

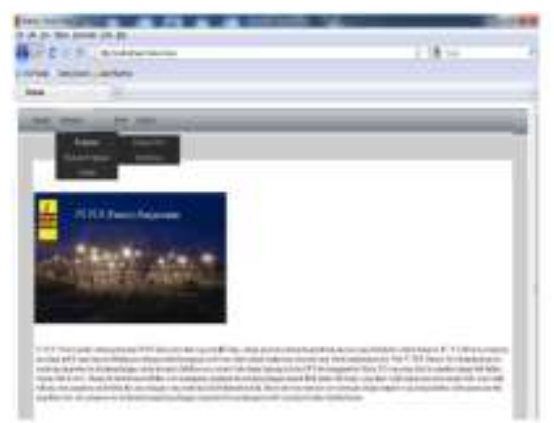

Gambar 6. Menu Utama Keluhan

\section{Form Pengaduan Pelanggan Baru}

Pada menu ini jika ada pelanggan memilih menu pengaduan pelanggan baru, maka akan 
muncul form yang akan di isi oleh pelanggan tentang identitas pelanggan dan jenis keluhan pelanggan. Form dari pengaduan pelanggan baru dapat dilihat seperti gambar berikut :

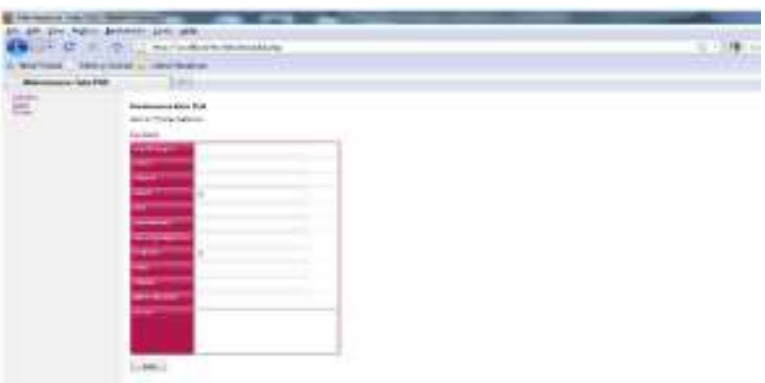

Gambar 7. Menu Pengaduan Pelanggan Baru

Sedangkan untuk form pengaduan tambah daya dapat dilihat seperti pada gambar berikut :

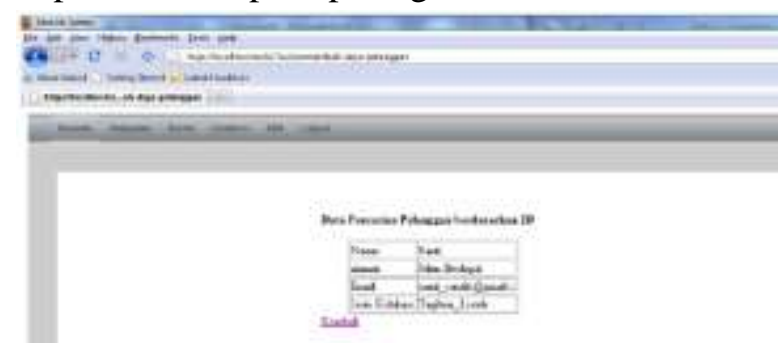

Gambar 8. Menu Pengaduan Tambah Daya

\section{Form Ringkasan Pengaduan}

Pada form ringkasan pengaduan terlihat bahwa jika login dilakukan admin maka akan mempunyai hak akses untuk melihat ringkasan pengaduan dan melakukan proses didalamnya. Serta dapat melihat statistik dari keluhan pelanggan, seperti pada gambar berikut :

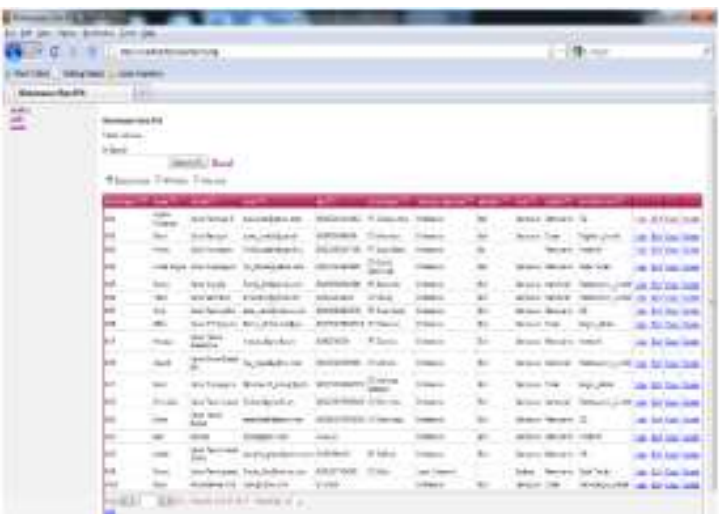

Gambar 9. Menu Ringkasan Pengaduan

Dan untuk statistik keluhan dapat dilihat pada gambar berikut ini, terlihat keluhan tertinggi ada pada bagian pemasaran.

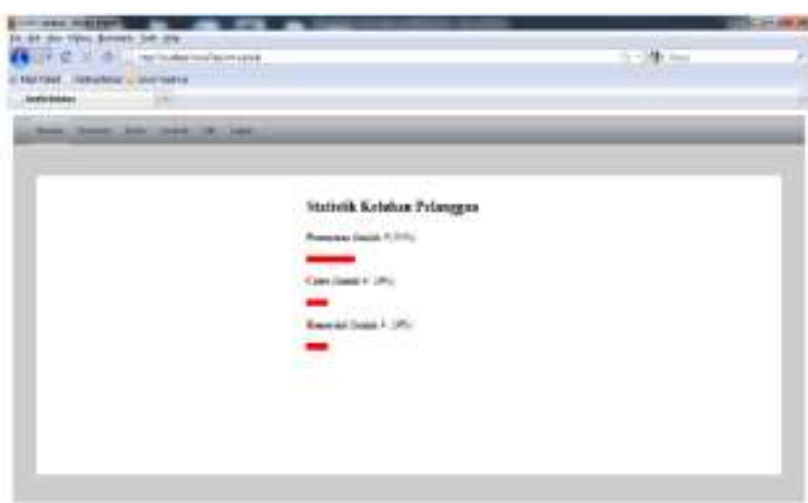

Gambar 10. Menu Statistik Keluhan Pelanggan

\section{Form Search Pelanggan}

Pada form ini terlihat bahwa data identitas pelanggan dapat di cari berdasarkan ID Pelanggan, hal ini bertujuan apabila nama dari pelanggan tersebut sama.

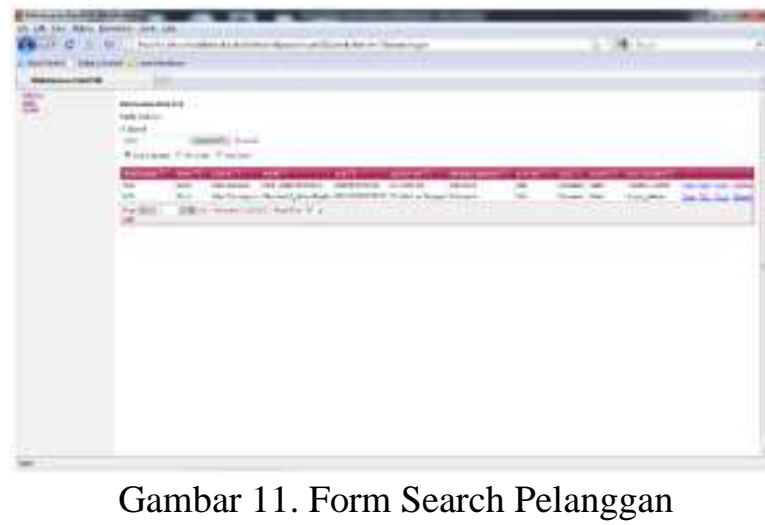

\section{Form Berita}

Dalam form berita ini dapat menampilkan informasi terbaru dari perusahaan. Sehingga para pelanggan tidak perlu datang langsung ke kantor untuk melihat berita terbaru. Dalam informasi berita ini berlaku untuk semua pelanggan. Baik itu pelanggan yang telah menjadi pelanggan lama ataupun masih menjadi calon pelanggan.

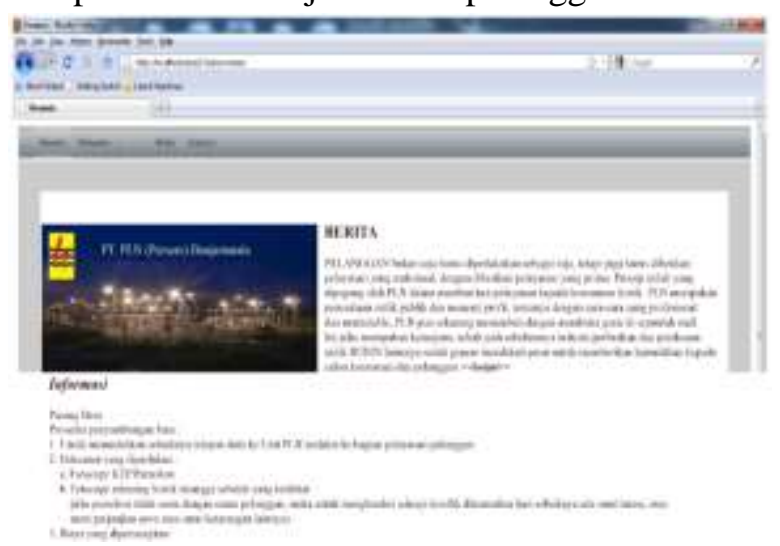

Gambar 12. Tampilan Berita dan Informasi 


\section{Form Contact Us}

Dalam menu ini akan diberikan informasi kontak kantor dan alamat kantor. Adapun tampilan contact us terlihat pada gambar berikut ini :

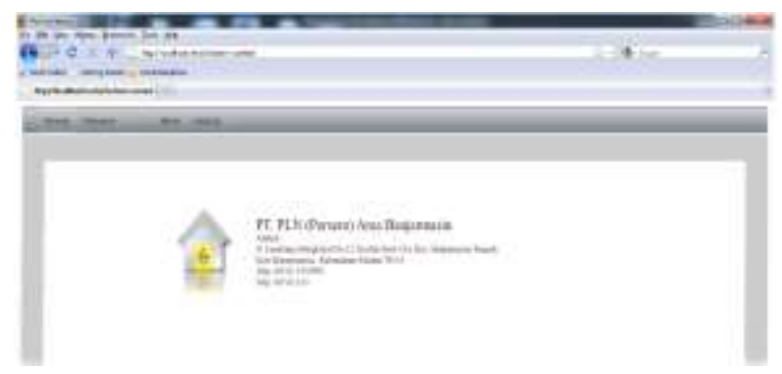

Gambar 13. Tampilan Contact Us

\section{Form Input Data Gangguan dan Keluhan Masuk}

Form Inputan Data Gangguan dan Keluhan Masuk merupakan form penginputan data lengkap data gangguan dan keluhan masuk dengan mengisi field yang telah tersedia. Berupa data Id Pelanggan, Nama, Tanggal Gangguan, Alamat, Telepon, Kecamatan, Kelurahan, Subjek, Bentuk Gangguan, Jenis Keluhan, Pesan. Berikut adalah gambar form Input Data Gangguan dan Keluhan Masuk adalah sebagai berikut:

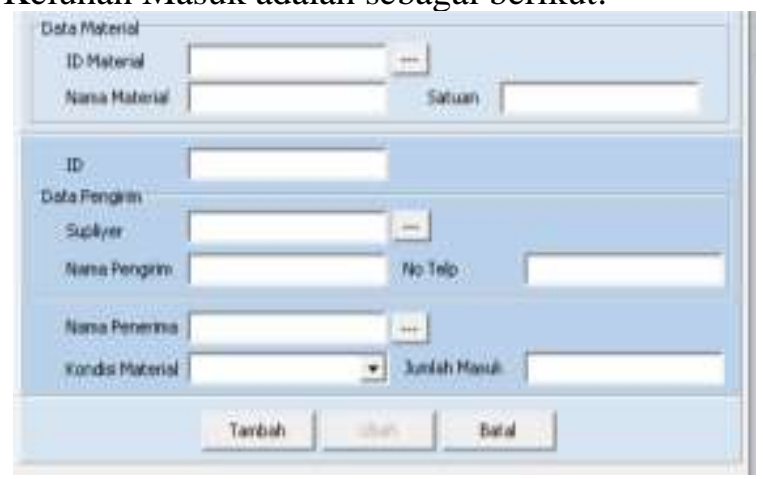

Gambar 14. Form Input Gangguan dan Keluhan Masuk

\section{Form Input Data Penanganan Gangguan dan Keluhan}

Form Inputan Data Penanganan Gangguan dan Keluahan Pelanggan selesai dengan mengisi field yang telah tersedia. Berupa data Id Pelanggan, Jenis Gangguan, Jenis Keluhan, Nama Pelanggan, Alamat, Lokasi, Eksekutor/Teknisi, Tanggal Penanganan. Berikut adalah gambar form Input Data Penanganan Gangguan dan Keluhan Selesai adalah sebagai berikut:

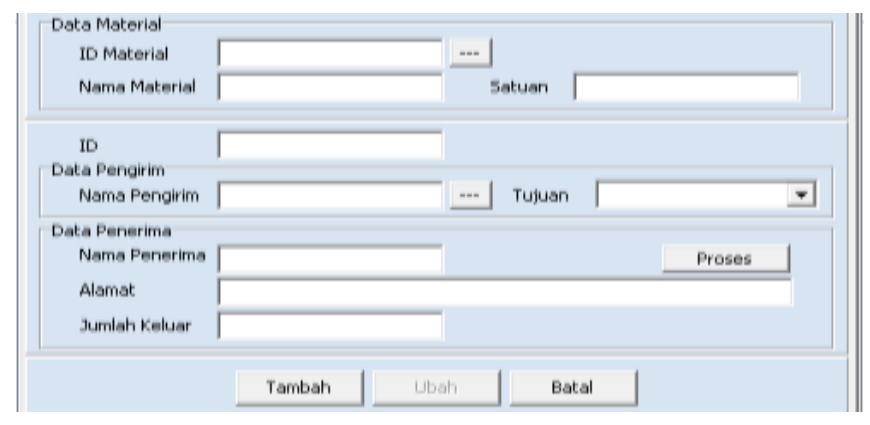

Gambar 15. Form Input Penanganan dan Keluhan Pelanggan

\section{Laporan Data Pegawai}

Laporan Data Pegawai adalah hasil keseluruhan dari data-data pegawai PT. PLN (Persero) Area Banjarmasin yang telah diinput dan tersimpan dalam database, kemudian yang dapat dijadikan sebagai laporan setiap bulannya. Berikut gambar laporan data anggota keseluruhan:

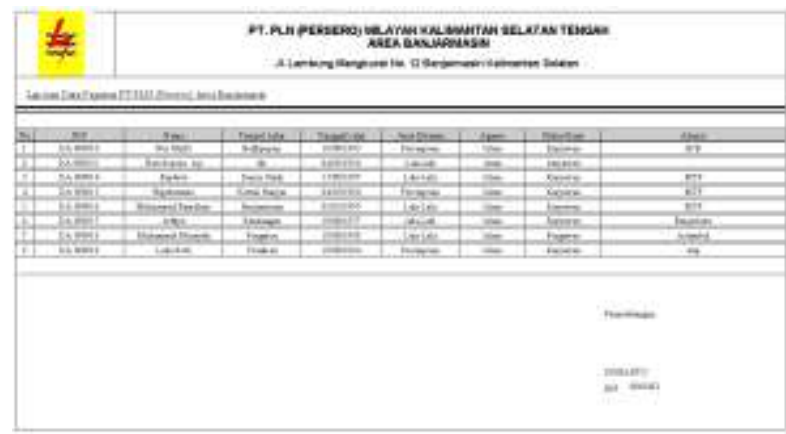

Gambar 16. Laporan Data Pegawai

\section{Laporan Data Pelanggan}

Laporan Data Pelanggan adalah hasil keseluruhan dari data pelanggan yang telah diinput dan tersimpan dalam database, kemudian dapat dijadikan sebagai laporan untuk memudahkan monitoring pelanggan. Berikut gambar laporan data pelanggan :

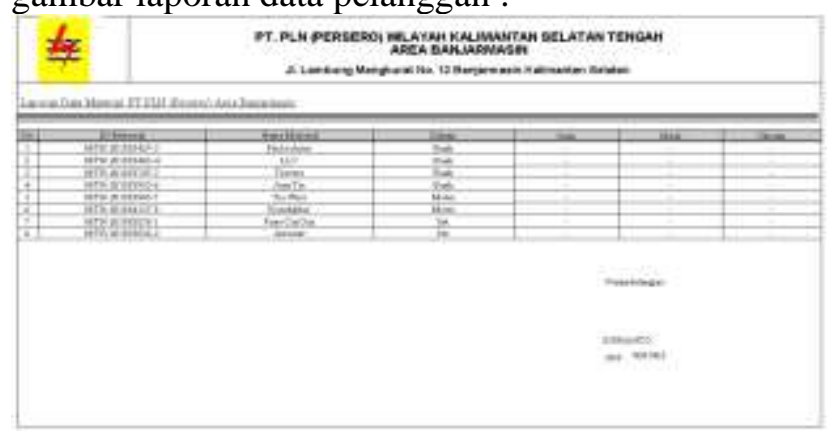

Laporan Data Pelanggan 


\section{PENUTUP}

\subsection{Kesimpulan}

Berdasarkan dari pembahasan, penulis dapat menarik beberapa kesimpulan sebagai berikut :

1. Dengan menggunakan aplikasi Monitoring Pelayanan Pengaduan dan Keluhan Pelanggan berbasis WEB maka para pegawai maupun teknisi sangat terbantu dengan sistem ini, karena selain membantu mempercepat penanganan gangguan dan keluhan pelanggan, data pun tersimpan dengan baik dan rapi.

2. Menghasilkan informasi yang akurat dan berkualitas, serta mempermudah perolehan data yang diinginkan, serta laporan yang cepat dan tepat.

3. Pengelolaan data berbasis komputer atau Web juga lebih aman dari gangguan pencurian data maupun serangan virus.

\subsection{Saran}

Agar mendapatkan hasil yang optimal adapun saran yang ingin penulis sampaikan setelah melakukan penelitian dengan menguraikan data yang di dapat, maka penulis menpunyai beberapa saran :

1. Guna mempercepat dan mempermudah kinerja pegawai PLN, sebaiknya digunakan program Aplikasi Monitoring Pelayanan Gangguan dan Keluhan Pelanggan berbasis Android dan SMS Gateway, sehingga para pegawai maupun yang berkepentingan lainnya lebih mudah mengakses dan memonitoring setiap gangguan dan keluhan yang masuk.

2. Perlu ditambahkannya filter pencarian data kerusakkan yang paling sering terjadi untuk laporan setiap bulannya.

3. Perlunya ada backup data guna melindungi keamanan data untuk kedepannya.

\section{DAFTAR PUSTAKA}

[1]. Kadir, A. (2008). Tuntunan Praktis : Belajar Database menggunakan MySQL. Yogyakarta: Andi.

[2]. Kadir, Abdul. (2013). Delphi From Zero To a Pro. Yogyakarta : Andi,.

[3]. Sigit, Suyantoro. (2006). Seri Panduan Praktis : Pengolahan Database MySQL. Yogyakarta : Andi.

[4]. Sutanta, Edhy. (2011). Basis Data dalam Tinjauan Konseptual. Yogyakarta : Andi

[5]. Agus Eka Pratama, Putu. 2014. Sistem Informasi dan Implementasinya. Bandung : Informatika Bandung.

[6]. AL Bahra Bin Ladjamudin, 2005. Analisis dan Desain Sistem Informasi, Graha Ilmu, Yogyakarta

[7]. Setiadi B, 2019. Aplikasi Monitoring Material Pergudangan Pada PT. PLN (Pesero) Area Banjarmasin. Technologia : Jurnal Ilmiah. 10 (4) : 179-193

[8]. Suja, Iman. 2007. Pemrograman SQL dan Database Server Mysql. Yogyakarta: Andi Publisher.

[9]. Setiadi B, 2018. Aplikasi Monitoring Penggantian Kwh Meter Rusak Pada PT. PLN Persero. Journal of Industrial Engineering And Operation Management. 1 (2) : 42-45 